\author{
Agnieszka Regiec* \\ ORCID: 0000-0002-5909-6196
}

Uniwersytet Wrocławski

DOI: $10.19195 / 1733-5779.26 .9$

\title{
Kierunki polityki UE w zakresie opieki zdrowotnej związanej ze starzeniem się społeczeństwa
}

Słowa kluczowe: polityka EU, zdrowie publiczne, opieka zdrowotna, transgraniczna opieka zdrowotna, społeczeństwo starzejące się, srebrna gospodarka

Keywords: EU policy, public health, health care, cross-border health care, aging society, silver economy

Abstrakt: Społeczeństwo Unii Europejskiej jest społeczeństwem starzejącym się, co generuje wzrost potrzeb w zakresie opieki zdrowotnej i ich skutków finansowych. Aby odpowiedzieć na wyzwania gospodarcze związane ze starzeniem się społeczeństwa, wdrożono program „Zdrowie na rzecz wzrostu gospodarczego". Dodatkowo w programie ramowym Horyzont 2020 zakładającym rozwój badań naukowych i innowacji jako jedno z wyzwań wskazano następujące kategorie: zdrowie, zmiany demograficzne i dobrostan. Dla polityki zdrowotnej UE kluczowe było także przyjęcie dyrektywy w sprawie stosowania praw pacjentów w transgranicznej opiece zdrowotnej.

\section{EU health care policy objectives in connection with the society growing older}

Abstract: European Union's society is aging, which generates the increase in needs regarding health care and its financial repercussions. In order to meet economic needs increased by ageing population, the Health for Growth Programme was commenced. Moreover Horizon 2020, the EU Framework Programme for Research and Innovation, will focus on, amongst societal challenges, health, demographic change and well-being. One of the other milestones for European health care was entering into force the Directive on the application of patients' rights in cross-border healthcare.

* Opiekun naukowy (Scientific Tutor) — Józef Frąckowiak

Studenckie Prace Prawnicze, Administratywistyczne i Ekonomiczne 26 


\section{Wstęp}

Nie ulega wątpliwości, że społeczeństwo Unii Europejskiej (dalej „UE”) jest społeczeństwem starzejącym się. Mimo iż wiedza ta jest powszechna, dopiero od niedawna w polityce UE na stałe pojawiły się związane z tym kwestie zdrowotne. Niniejsze opracowanie ma przybliżyć czytelnikowi prawne oraz ekonomiczne aspekty polityki zdrowotnej UE związanej z kryzysem gospodarczym. W odniesieniu do części publikacji dotyczącej prawa UE, zastosowana będzie klasyczna metoda formalnodogmatyczna polegająca na analizie przepisów prawa, wzbogacona o kluczową dla zrozumienia prawa UE analizę orzecznictwa Trybunału Sprawiedliwości Unii Europejskiej (dalej „TSUE”). Posiłkowo wskazane zostaną dane statystyczne.

Prognozy statystyczne Eurostatu w zakresie przewidywanej liczby ludności w UE, oparte na kryterium wieku, wskazują, że w 2080 roku liczba osób po 65. roku życia wyniesie aż $28,7 \%$ całości populacji, czyli $149,1 \mathrm{mln}$. Dla porównania w 2014 roku dane te wynosiły odpowiednio $18,5 \%$ oraz $93,9 \mathrm{mln}^{1}$. Należy wskazać, że nie tylko nastąpi wzrost liczby osób w wieku powyżej 65 lat, lecz także zmniejszy się liczba osób w wieku produkcyjnym (working-age population) — w roku 2014 wynosiła ona 56,2\% całości populacji czyli 338,8 mln. Prognozy wskazują, że począwszy od 2035 roku, liczba ta spadnie poniżej $60 \%$ populacji w Unii Europejskiej i będzie się utrzymywała, a w roku 2080 będzie wynosiła $56,2 \%$ całości populacji. Spadek ten jest równoważny ze zmniejszeniem liczby osób w wieku produkcyjnym aż o $41,5 \mathrm{mln}^{2}$. Jeżeli chodzi zaś o liczbę dzieci, to również będzie się ona zmniejszała — w 2014 roku wynosiła 15,6\% całości populacji, z kolei w roku 2080 wyniesie $15,1 \%{ }^{3}$. Powyższe dane liczbowe należy odnieść do wzrastających kosztów utrzymania społeczeństwa się starzejącego. Są to koszty poniesione między innymi na służbę zdrowia oraz świadczenia emerytalne ${ }^{4}$. Pojawia się zatem pytanie o to, skąd pozyskać środki na te cele. W związku $\mathrm{z}$ tym jednym z wyzwań srebrnej gospodarki jest dostosowanie systemu zdrowia do stale zwiększającej się liczby osób w wieku emerytalnym.

$\mathrm{W}$ analizowanym zagadnieniu istotne są cztery kwestie:

1. odróżnienie polityki UE w zakresie zdrowia publicznego od polityki UE w zakresie opieki zdrowotnej;

2. swobodny przepływ pacjentów oraz profesjonalnej służby zdrowia;

3. wpływ polityki UE w zakresie opieki zdrowotnej oraz swobodnego przepływu pacjentów i profesjonalnej służby zdrowia na rozwój gospodarczy UE;

${ }^{1}$ Eurostat Statistical Books, People in the EU: who are we and how do we live?, 2015, s. 161, https://ec.europa.eu/eurostat/documents/3217494/7089681/KS-04-15-567-EN-N.pdf (dostęp: grudzień 2016).

2 Ibidem.

3 Ibidem.

4 Zob. szerzej European Commission, The Ageing Report, Economic and budgetary projections for the 28 EU Member States (2013-2060), European Economy 2015, nr 3. 
4. wymiana doświadczeń państw członkowskich związanych ze zmianami w systemach zdrowotnych oraz stopień poinformowania pacjentów o przysługujących im prawach w przypadku transgranicznej opieki zdrowotnej oraz o możliwości ubiegania się o zwrot kosztów leczenia za granicą.

\section{Zdrowie publiczne a opieka zdrowotna - wyłączna kompetencja państw członkowskich?}

Może się wydawać, że Unia Europejska późno podjęła taką inicjatywę jak program „Zdrowie na rzecz wzrostu gospodarczego” (dalej „Program”). Aby móc wyjaśnić te potencjalne wątpliwości, warto, po pierwsze, wskazać, że ochrona zdrowia nie należy do kompetencji wyłącznych UE (art. 3 ust. 1 TfUE). Dopiero art. 6 TfUE przyznaje UE kompetencje do prowadzenia działań mających na celu wspieranie, koordynowanie lub uzupełnianie działań państw członkowskich w zakresie między innymi ochrony i poprawy zdrowia ludzkiego. Łącznie z tymi przepisami należy rozpatrywać art. 4 ust. 1 TUE, który stanowi, że wszelkie kompetencje nieprzyznane UE w Traktatach należą do państw członkowskich. Ponadto art. 5 ust. 1 wyraźnie wskazuje, że granice kompetencji UE wyznacza zasada przyznania. Zatem opieka zdrowotna pozostaje do wyłącznej kompetencji państw członkowskich ${ }^{5}$. Z tego względu, mimo potrzeby podjęcia działań w zakresie opieki zdrowotnej na szczeblu europejskim, instytucje UE ostrożnie prowadzą politykę w tej kwestii. Często gdy potrzebna jest ingerencja w zakresie opieki zdrowotnej, legitymacji poszukuje się w upoważnieniu do działania $\mathrm{w}$ innych dziedzinach, niezwiązanych stricte z opieką zdrowotną ${ }^{6}$.

W kwestii pojęcia zdrowia publicznego należy odnotować, że definicja ta ewaluowała. Według klasycznej definicji Winslowa zdrowie publiczne to nauka i sztuka: zapobiegania chorobom; przedłużania życia i promocji zdrowia fizycznego poprzez wysiłek społeczności; higieny środowiska, kontroli zakażeń, nauczania zasad higieny indywidualnej, organizacji służb medycznych i pielęgniarskich, ukierunkowania na zapobieganie chorobom i wczesną diagnozę; rozwoju mechanizmów społecznych zapewniających każdemu indywidualnie oraz społeczności warunki życia pozwalające na utrzymanie zdrowia ${ }^{7}$. Definicję tę zmodyfikował Acheson, wprowadzając pojęcie nowego zdrowia publicznego, które stanowi, że zdrowie publiczne to nauka i sztuka zapobiegania chorobom, przedłużania życia, promowania zdrowia poprzez zorganizowany wysiłek społeczeństwa ${ }^{8}$.

${ }^{5}$ H. Legido-Quigley, Assuring the Quality of health Care in the European Union: A Case for Action, World Health Organization, Brussels 2008, s. 193.

${ }^{6}$ W. Lamping, European Union health care policy, [w:] European Public Health Policy: Regional and Global Trends, red. S.L. Greer, P. Kurzer, London 2013, s. 20.

7 C.E.A. Winslow, The untilled fields of public health, „Science N.S.” 51, 1920, s. 22-33.

8 http://www.euro.who.int/en/health-topics/Health-systems/public-health-services (dostęp: grudzień 2016). Zob. także J.M. Martin-Moreno, A Systematic Approach to Public Health Oper- 


\section{Program „Zdrowie na rzecz wzrostu gospodarczego”}

Aby odpowiedzieć na potrzeby gospodarcze związane ze starzeniem się społeczeństwa, wdrożono program ,Zdrowie na rzecz wzrostu gospodarczego” (20142020). Jest on trzecim wieloletnim programem działania Unii Europejskiej. Omówione zostaną pokrótce: sytuacja faktyczna w zakresie średniej długości życia i ochrony zdrowia; cele szczegółowe Programu; kwestie finansowe Programu, w tym wpływ na budżet; aspekty prawne Programu; oczekiwane wyniki Programu. Aby ułatwić zadanie Komisji w jego promowaniu, upowszechnianiu wyników oraz informowaniu o skutkach wynikających z jego realizacji, utworzono krajowe punkty kontaktowe (art. 14 rozporządzenia').

\subsection{Sytuacja faktyczna}

Chociaż średnia długość życia w UE się wydłuża, to średnia liczba lat zdrowego życia zwiększa się znacznie wolniej. W rezultacie większa część dłuższego życia przeżywana jest w złym stanie zdrowia, co, jak podkreśla się w rozporządzeniu Parlamentu Europejskiego i Rady w sprawie ustanowienia programu „Zdrowie na rzecz wzrostu gospodarczego", jest jednym z czynników prowadzących do szybkiego wzrostu kosztów związanych ze służbą zdrowia i z utrudnionym uczestnictwem w rynku pracy. Podkreśla się, że zły stan zdrowia wywiera negatywny wpływ na rozwój kapitału ludzkiego, który ma decydujące znaczenie dla rozwoju gospodarki. Należy odnotować, że to choroby przewlekłe są główną przyczyną zgonów w Europie ${ }^{10}$. Dlatego Program zakłada profilaktykę chorób przewlekłych.

\subsection{Cele szczegółowe Programu}

Do celów szczegółowych Programu należą:

1. zwiększanie innowacyjności i stabilności systemów opieki zdrowotnej;

2. zwiększanie dostępu do lepszej i bezpieczniejszej opieki zdrowotnej dla obywateli UE;

3. promocja zdrowia i zapobieganie chorobom;

4. ochrona obywateli przed transgranicznymi zagrożeniami dla zdrowia (art. 3 rozporządzenia).

ations and Services: Towards Positive Coordination with Health Care and Other Services, World Health Organization, Europe, 2011, s. 7, http://www.euro.who.int/_data/assets/pdf_file/0003/135507/ JMM_PHS_strengthenings.pdf?ua=1 (dostęp: grudzień 2016).

${ }^{-}$Wniosek - rozporządzenie Parlamentu Europejskiego i Rady w sprawie ustanowienia programu ,Zdrowie na rzecz wzrostu gospodarczego", trzeciego wieloletniego programu działań UE w dziedzinie zdrowia na lata 2014-2020. KOM (2011) wersja ostateczna, 2011/0339 COD, s. 8, https://eur-lex.europa.eu/legal-content/PL/TXT/?uri=celex:52011PC0709 (dostęp: styczeń 2017). Dalej „rozporządzenie”.

10 Ponad 4 mln ludzi w UE umiera z powodu chorób przewlekłych. Zob. szerzej Eurostat Statistical Books, op. cit. 
Cel szczegółowy nr 1 realizowany jest poprzez działania kwalifikowane polegające między innymi na rozwijaniu współpracy na szczeblu UE w dziedzinie oceny technologii medycznych w kontekście dyrektywy 2011/24/UE w sprawie stosowania praw pacjentów w transgranicznej opiece zdrowotnej ${ }^{11}$. Ponadto promuje się wdrażanie innowacji $\mathrm{w}$ dziedzinie zdrowia oraz e-zdrowia. Program zapewnia również wsparcie $\mathrm{w}$ ramach Europejskiego partnerstwa na rzecz innowacji sprzyjającej aktywnemu starzeniu się w dobrym zdrowiu ${ }^{12}$. Omawiany cel szczegółowy realizowany będzie także w ramach prawodawstwa UE — zwłaszcza w dziedzinie wyrobów medycznych oraz oceny technologii medycznych w prawodawstwie dotyczącym transgranicznej opieki zdrowotnej.

Cel szczegółowy $\mathrm{nr} 2$ realizowany jest poprzez tworzenie systemów akredytacji i wsparcia europejskich sieci referencyjnych, informacji i rejestrów, a także poprzez opracowanie wytycznych europejskich w zakresie bezpieczeństwa pacjentów oraz rozważnego stosowania środków przeciwdrobnoustrojowych. Podkreślenia wymaga, że omawiany cel zakłada opracowanie wytycznych w celu ograniczenia praktyk zwiększających oporność na środki przeciwdrobnoustrojowe.

Realizacja celu szczegółowego nr 3 opiera się na wymianie najlepszych praktyk dotyczących zapobiegania uzależnieniu od tytoniu, nadużywania alkoholu oraz otyłości. Proponowane są także specjalne działania w obszarze profilaktyki chorób przewlekłych, w tym nowotworów. Natomiast cel szczegółowy nr 4 opiera się na wzmacnianiu gotowości do reagowania na poważne transgraniczne zagrożenia dla zdrowia. Poziom gotowości i reagowania w sytuacjach kryzysowych wymaga poprawy.

\subsection{Aspekty finansowe}

Przydział środków finansowych na realizację Programu wynosi 446 mln EUR na okres od 1 stycznia 2014 do 31 grudnia 2020 roku (art. 5 rozporządzenia). W Programie mogą uczestniczyć wszystkie państwa członkowskie UE, a także państwa trzecie. Wśród państw trzecich należy wyróżnić w szczególności: państwa przystępujące do UE, państwa kandydujące, państwa Europejskiego Stowarzyszenia Wolnego Handlu (EFTA) oraz państwa Europejskiego Obszaru Gospodarczego (EOG), państwa sąsiedzkie i państwa, do których znajduje zastosowanie europejska polityka sąsiedztwa (ENP). Wkład finansowy UE może przybierać formę dotacji lub zamówień publicznych ${ }^{13}$.

11 Dyrektywa 2011/24/UE Parlamentu Europejskiego i Rady z dnia 9 marca 2011 roku, Dz.U. L 88/46 z 4.04.2011.

12 Europejskie partnerstwo na rzecz innowacji sprzyjającej aktywnemu starzeniu się w dobrym zdrowiu — projekt pilotażowy w ramach inicjatywy przewodniej strategii „Europa 2020” — COM (2010) 546 - wersja ostateczna.

${ }^{13}$ Lub innych interwencji niezbędnych do osiągnięcia celów Programu — art. 7 rozporządzenia. 
Procedura pozyskiwania środków finansowych zostanie znacznie uproszczona. Przewidziano zmniejszenie kosztów uczestniczenia, przyspieszenie procedur przyznawania dotacji oraz zapewnienie ,punktów kompleksowej obsługi” w celu ułatwienia beneficjentom dostępu do finansowania unijnego. Program wykorzysta w maksymalnym stopniu przepisy zmienionego rozporządzenia finansowego UE, w szczególności poprzez dalsze uproszczenie wymogów w zakresie sprawozdawczości, włącznie z szerszym stosowaniem przekazywania sprawozdań drogą elektroniczną.

\subsection{Aspekty prawne wniosku}

We wniosku wskazano, że działanie na szczeblu UE jest uzasadnione zarówno $\mathrm{z}$ racji celów określonych $\mathrm{w}$ art. 168 TfUE, jak i na podstawie zasady pomocniczości. Przedmiotowy artykuł stanowi, że przy określaniu i urzeczywistnianiu wszystkich polityk i działań Unii zapewnia się wysoki poziom ochrony zdrowia ludzkiego. Działanie Unii, które uzupełnia polityki krajowe, nakierowane jest na poprawę zdrowia publicznego, zapobieganie chorobom i dolegliwościom ludzkim oraz usuwanie źródeł zagrożeń zdrowia fizycznego i psychicznego. Dodatkowo ust. 2 omawianego artykułu wskazuje, że w ścisłym kontakcie z państwami członkowskimi Komisja może podjąć każdą użyteczną inicjatywę w celu wsparcia tej koordynacji, w szczególności inicjatywy mające na celu określenie wytycznych i wskaźników, organizowanie wymiany najlepszych praktyk i przygotowanie elementów niezbędnych dla prowadzenia okresowego nadzoru i oceny. Ponadto art. 168 ust. 5 TfUE upoważnia Parlament Europejski i Radę do ustanawiania środków zachęcających, zmierzających do ochrony i poprawy zdrowia ludzkiego. Podejmowane środki prawne nie mogą polegać na jakiejkolwiek harmonizacji przepisów ustawowych i wykonawczych państw członkowskich ze względu na wskazany na początku niniejszego opracowania brak kompetencji UE w zakresie opieki zdrowotnej.

Podkreślenia wymaga, że zgodnie z art. 13 rozporządzenia, nie później niż w połowie 2018 roku, Komisja sporządzi sprawozdanie z oceny w sprawie osiągnięcia celów wszystkich działań, efektywności wykorzystania zasobów oraz wartości dodanej Programu w celu podjęcia decyzji w sprawie przedłużenia, zmiany lub zawieszenia działań. Ocena powinna uwzględniać ewentualną możliwość w zakresie uproszczenia Programu.

\section{Program Horyzont 2020}

Program Horyzont 2020 (dalej „H2020”) jest programem ramowym w zakresie badań naukowych i innowacji. Inwestycje i badania prowadzone w ramach H2020 wpisują się w strategię Europa 2020 i mają na celu inteligentny i trwały wzrost gospodarczy sprzyjający włączeniu społecznemu. Ramy prawne programu określone zostały, co do zasady, w dwóch głównych rozporządzeniach: 1. rozporządzenie 
Parlamentu Europejskiego i Rady (UE) nr 1290/2013 z dnia 11 grudnia 2013 roku ustanawiające zasady uczestnictwa i upowszechniania Programu „Horyzont 2020” — programu ramowego w zakresie badań naukowych i innowacji (2014-2020) ${ }^{14}$ oraz uchylające rozporządzenie (WE) nr 1906/2006; oraz 2. rozporządzenie Parlamentu Europejskiego i Rady (UE) nr 1291/2013 z dnia 11 grudnia 2013 roku ustanawiające „Horyzont 2020” — programem ramowym w zakresie badań naukowych i innowacji (2014-2020) oraz uchylające decyzję nr 1982/2006/WE ${ }^{15}$.

Zdefiniowano siedem wyzwań priorytetowych, w ramach których ukierunkowane będą inwestycje w badania naukowe i innowacje. W dziedzinie zdrowia wskazane zostały następujące:

1. zdrowie, zmiany demograficzne i dobrostan;

2. bezpieczeństwo żywnościowe, zrównoważone rolnictwo i leśnictwo, badania mórz i wód śródlądowych oraz biogospodarka;

3. bezpieczna, czysta i efektywna energia;

4. inteligentny, ekologiczny i zintegrowany transport;

5. działania w dziedzinie klimatu, środowisko, efektywna gospodarka zasobami i surowce;

6. Europa w zmieniającym się świecie — integracyjne, innowacyjne i refleksyjne społeczeństwa;

7. bezpieczeństwo społeczeństwa - ochrona wolności i bezpieczeństwa Europy i jej obywateli ${ }^{16}$.

Na badania i inwestycje w zakresie zdrowia przeznaczono dofinansowanie w wysokości 7,472 mld euro ${ }^{17}$. Program ten, jako inwestycja wieloletnia, zakłada wielopłaszczyznowe cele realizowane z takim samym natężeniem we wszystkich krajach UE, dlatego że należy minimalizować ryzyko rozprzestrzeniania się chorób zakaźnych. Do celów tych należą: uświadamianie społeczeństwa o tym, jak dbać o zdrowie w okresie starości; podniesienie świadomości o chorobach; wczesne wykrywanie chorób, oparte na między innymi kampaniach informacyjnych oraz skutecznych programach badań przesiewowych; wspieranie osób starszych w tym, by pozostawały aktywne i zdrowe; testowanie i wcielanie w życie nowych modeli i narzędzi dla zachowania zdrowia. Ponadto przy realizacji programu prowadzona będzie współpraca z takimi funkcjonującymi już inicjatywami, jak: European Innovation Partnership on Active and Healthy Ageing; Joint Programming Initiative - More Years Better Lives — The Potential and Challenges of Demographic Change ${ }^{18}$.

14 Dz.U. L 347/81 z 20 grudnia 2013 roku.

15 Dz.U. L 347/104 z 20 grudnia 2013 roku.

16 Rozporządzenie 1291.2013, załącznik I, Ogólne kierunki celów szczegółowych i działań, priorytet „Wyzwania Społeczne”, s. 124.

17 Horizon 2020 w skrócie, Komisja Europejska, 2014, s. 11.

18 Czytamy na stronie https://ec.europa.eu, w opisie programu Horyzont 2020. 


\section{Przepływ pacjentów}

Zarówno w badaniach nad opieką zdrowotną w krajach UE, jak i w orzecznictwie Trybunału Sprawiedliwości Unii Europejskiej widoczne jest zainteresowanie problematyką migracji osób w wieku emerytalnym. Wskazuje się, że osoby te wymagają innej opieki zdrowotnej niż turyści, chociażby dlatego, że przemieszczają się z zamiarem pobytu długoterminowego. Pojawia się wówczas pytanie o zakres świadczeń, do jakich będą uprawnione. W doktrynie podkreśla się, że wiele osób z krajów Europy Północnej w wieku emerytalnym przenosi się do krajów Europy Południowej, na przykład do Hiszpanii, Portugalii, Francji, Włoch, Grecji, Chorwacji, Bułgarii. W krajach Europy Południowej opieka socjalna dla osób korzystających ze świadczeń emerytalnych tradycyjnie spoczywała na rodzinie. Zupełnie inny jest zakres świadczeń emerytalnych dla obywateli krajów Europy Północnej, gdzie zazwyczaj mamy do czynienia z szeroko rozwiniętym publicznym systemem opieki zdrowotnej ${ }^{19}$.

Przepływ pacjentów dotyczy jednak nie tylko osób w wieku emerytalnym. Orzecznictwo TSUE w zakresie swobodnego przepływu pacjentów sięga końca lat dziewięćdziesiątych. W precedensowych orzeczeniach TSUE stwierdził, że system zdrowotny wchodzi w zakres swobodnego przepływu usług. Są to w szczególności następujące orzeczenia: Kohll v. Union de Caisses de Maladie ${ }^{20}$, Decker v. Caisse maladie des emmployes prives ${ }^{21}$, Geraets-Smits v. Stiching Ziekenfonds VGZ ${ }^{22}$, Watts v. Bedford Primary Care Trust ${ }^{23}$ oraz Vanbraekel i inni ${ }^{24}$. W sprawach tych pojawiły się między innymi kwestie wysokości zwrotu kosztów opieki zdrowotnej poniesionych za granicą czy brak uzyskania uprzedniej zgody państwa członkowskiego ubezpieczenia na wykonanie zabiegu $\mathrm{w}$ innym państwie członkowskim ${ }^{25}$. Przedmiotowe orzeczenia, chociaż zostały wydane

19 H. Legido-Quigley, Assuring the Quality of Health Care in the European Union: A Case for Action, World Health Organization 2008.

${ }^{20}$ Wyrok TSUE w sprawie C-158/96 Raymond Kohll v Union des caisses de maladie, [1998] ECR I-1931.

21 Wyrok TSUE w sprawie C-120/9 5 Nicolas Decker v Caisse de maladie des employés privés, [1998] ECR. I-1831.

22 Wyrok TSUE w sprawie C-157/99 B.S.M. Geraets-Smits $v$ Stichting Ziekenfonds VGZ and H.T.M. Peerbooms v Stichting CZ Groep Zorgverzekeringen, [2001] ECR I-5473.

23 Wyrok TSUE w sprawie C-372/04 Yvonne Watts v. Bedford Primary Care Trust and Secretary of State for Health, [2006] ECR I-04325.

24 Wyrok TSUE w sprawie C-368/98 Vanbraekel and Others, [2001] ECR I-05363.

25 A. Baeyens, Free movement of goods and services in health care: a comment on the Court cases Decker and Kohll from a Belgian point of view, „European Journal of Health Law” 1999, nr 6, s. 373 n.; B. Reinhard, Border-crossing patients in the EU, „Eurohealth” 2002, nr 8, s. 19 n.; C. Pedro, Cross-border medical care in the European Union - bringing down a first wall, „European Law Review" 1999, nr 24, s. 387 n.; oraz C. Pedro, The internal market and the right to cross-border medical care, „European Law Review” 2004, nr 29, s. 673; G. Richard, Case C-120/95, Nicolas Decker v. Caisse de maladie des employés privés, Judgment of 28 April 1998; 
w zakresie rynku wewnętrznego, pociągają za sobą daleko idące skutki dla sektora opieki zdrowotnej ${ }^{26}$. Następujące kwestie związane z rynkiem wewnętrznym mają odniesienie do opieki zdrowotnej: 1. swobodny przepływ osób oznacza też przepływ profesjonalnej służby zdrowia, a także obejmuje kwestie wzajemnego, automatycznego uznawania uprawnień i dyplomów; 2. obywatele UE powinni mieć dostęp do opieki zdrowotnej na terytorium całej UE; 3. przepływ towarów dotyczy produktów medycznych (w tym leków) oraz technologii medycznych; 4. przepływ usług dotyczy transgranicznego dostarczania świadczeń zdrowotnych; 5. przepływ kapitału powinien umożliwiać inwestycje szpitalne ${ }^{27}$. Kwestie te wykraczają jednakże znacznie poza zakres niniejszego opracowania, dlatego zostały tylko zasygnalizowane.

Dopiero w 2011 roku przyjęto dyrektywę praw pacjenta, czyli dyrektywę w sprawie stosowania praw pacjentów $\mathrm{w}$ transgranicznej opiece zdrowotnej ${ }^{28}$. W samej preambule dyrektywy wskazano, że podstawą do jej wydania jest art. 114 TfUE, gdyż większość przepisów dyrektywy ma na celu ulepszenie funkcjonowania rynku wewnętrznego i swobodnego przepływu towarów, osób i usług. Wśród celów wskazano, że pacjentom, pracownikom służby zdrowia, świadczeniodawcom oraz instytucjom zabezpieczenia społecznego należy zapewnić większą pewność prawną w zakresie zwrotu kosztów opieki zdrowotnej. Podkreślono jednocześnie, że wysokość finansowania kosztów opieki zdrowotnej poniesionej w innym państwie członkowskim ${ }^{29}$ będzie wynosiła co najmniej tyle, ile w przypadku takiego samego świadczenia w państwie członkowskim ubezpieczenia. Stąd niezwykle ważne jest, aby państwa członkowskie określiły zakres ubezpieczenia zdrowotnego dostępnego ich obywatelom. W związku z przyjęciem dyrektywy wskazywano potencjalne ryzyka. Zauważono, że może dojść do zmniejszenia zakresu usług refundowanych przez państwa członkowskie. Podkreślano możliwość wzrostu opłat za ubezpieczenie zdrowotne, sygnalizowano wydłużanie czasu oczekiwania na zabiegi oraz zmniejszenie liczby placówek drugiego stopnia ${ }^{30}$.

Case C-158/96, Raymond Kohll v. Union des caisses de maladie, Judgment of 28 April 1998, „Common Market Law Review" 1999, nr 36, s. 841 n.

26 V.G. Hatzopoulos, Do the rules on internal market affect national health care systems?, [w:] The Impact of EU Law on Health Care Systems, red. M. McKee, E. Mossialos, R. Baeten, Brussels 2002, s. 123 oraz T.K. Hervey, The legal basics of European Community Public Health Policy, [w:] The Impact of EU Law..., s. 23.

27 W. Lamping, op. cit., s. 26.

28 Dyrektywa Parlamentu Europejskiego i Rady 2011/24/UE z dnia 9 marca 2011 roku w sprawie stosowania praw pacjentów w transgranicznej opiece zdrowotnej, Dz.U. L 88/45 z 4.04.2011.

29 W okolicznościach innych niż określone w rozporządzeniu WE nr 883/2004.

30 Por. B. Catherine, Social dumping and the race to the Bottom: Some lessons for the EU from Delaware, „European Law Review” 25, 2000, s. 57. 


\section{Zakończenie i wnioski}

Chociaż formalnie kwestia opieki zdrowotnej pozostaje w wyłącznej kompetencji państw członkowskich, na poziomie UE podejmowane są działania zmierzające do przeciwdziałania niekorzystnym skutkom gospodarczym zmian demograficznych. Z jednej strony UE poprzez wdrożenie programu ,Zdrowie na rzecz wzrostu gospodarczego" zmierza do opracowania wspólnych mechanizmów służących rozwiązywaniu problemu niedoborów zasobów ludzkich oraz finansowych w opiece zdrowotnej. Z drugiej — poprzez oddziaływanie przepływu pacjentów, służby zdrowia (jako przepływu osób), a także przepływu usług i towarów na rynek wewnętrzny UE możliwe było wprowadzenie między innymi dyrektywy w sprawie stosowania praw pacjentów w transgranicznej opiece zdrowotnej. Niestety, jak wskazują dane, liczba wniosków o udzielenie informacji dotyczących leczenia za granicą składanych w krajowych punktach kontaktowych jest wciąż niska ${ }^{31}$. Co ciekawe, najwięcej wniosków złożono w Polsce — było ich aż 31736 w 2015 roku, na drugim miejscu uplasowała się Wielka Brytania, gdzie takich wniosków złożono tylko $8471^{32}$. W Polsce liczba wniosków niemal czterokrotnie przekroczyła liczbę wniosków otrzymanych w którymkolwiek innym państwie członkowskim. Na koniec należy podkreślić, że niezbędne jest przyspieszenie działań szczególnie w zakresie informowania pacjentów o ich prawach.

\section{Bibliografia}

Baeyens A., Free movement of goods and services in health care: a comment on the Court cases Decker and Kohll from a Belgian point of view, „European Journal of Health Law” 1999, nr 6.

Catherine B., Social dumping and the Race to the Bottom: Some lessons for the EU from Delaware, „European Law Review” 25, 2000.

European Commission, The Ageing Report, Economic and budgetary projections for the $28 \mathrm{EU}$ Member States (2013-2060), „European Economy” 2015, nr 3.

Europejskie partnerstwo na rzecz innowacji sprzyjającej aktywnemu starzeniu się w dobrym zdrowiu — projekt pilotażowy w ramach inicjatywy przewodniej strategii „Europa 2020” — COM (2010) 546 - wersja ostateczna.

Hatzopoulos V.G., Do the rules on internal market affect national health care systems?, [w:] The Impact of EU Law on Health Care Systems, red. M. McKee, E. Mossialos, R. Baeten, Brussels 2002.

Hervey T.K., The legal basics of European Community Public Health Policy, [w:] The Impact of EU Law on Health Care Systems, red. M. McKee, E. Mossialos, R. Baeten, Brussels 2002.

Lamping W., European Union health care policy, [w:] European Public Health Policy: Regional and Global Trends, red. S.L. Greer, P. Kurzer, London 2013.

Legido-Quigley H., Assuring the Quality of health Care in the European Union: A Case for Action, World Health Organization 2008.

Martin-Moreno J.M., A systematic approach to public health operations and services: Towards positive coordination with health care and other services, World Health Organization, Europe, 2011.

31 European Commission, Member State Data on cross-border healthcare following Directive 2011/24/EU, year 2015, s. 9 .

32 Ibidem. 
Pedro C., Cross-border medical care in the European Union - bringing down a first wall, „European Law Review" 24, 1999.

Reinhard B., Border-crossing patients in the EU, „Eurohealth” 2002, nr 8.

Richard G., Case C-120/95, Nicolas Decker v. Caisse de maladie des employés privés, Judgment of 28 April 1998, Case C-158/96, Raymond Kohll v. Union des caisses de maladie, Judgment of 28 April 1998, „Common Market Law Review” 1999, nr 36.

Winslow C.E.A., The untilled fields of public health, „Science N.S.” 51, 1920.

Wniosek - rozporządzenie Parlamentu Europejskiego i Rady w sprawie ustanowienia progra$\mathrm{mu}$,Zdrowie na rzecz wzrostu gospodarczego", trzeciego wieloletniego programu działań UE w dziedzinie zdrowia na lata 2014-2020. KOM (2011) wersja ostateczna, 2011/0339 COD.

\section{Orzecznictwo}

Wyrok TSUE w sprawie C-158/96 Raymond Kohll v Union des caisses de maladie, [1998] ECR I-1931.

Wyrok TSUE w sprawie C-120/9 5 Nicolas Decker v Caisse de maladie des employés privés, [1998] ECR. I-1831.

Wyrok TSUE w sprawie C-157/99 B.S.M. Geraets-Smits v Stichting Ziekenfonds VGZ and H.T.M. Peerbooms v Stichting CZ Groep Zorgverzekeringen, [2001] ECR I-5473.

Wyrok TSUE w sprawie C-372/04 Yvonne Watts v. Bedford Primary Care Trust and Secretary of State for Health, [2006] ECR I-04325.

Wyrok TSUE w sprawie C-368/98 Vanbraekel and Others, [2001] ECR I-05363.

\section{EU health care policy objectives in connection with the society growing older}

Summary

European Union's society is aging, which generates the increase in needs regarding health care and its financial repercussions. In order to meet economic needs increased by ageing population, the Health for Growth Programme was commenced. Moreover Horizon 2020, the EU Framework Programme for Research and Innovation, will focus on, amongst societal challenges, health, demographic change and well-being. One of the other milestones for European health care was entering into force the Directive on the application of patients' rights in cross-border healthcare. One of the most pertinent issues is the information access for all patients.

The Multi-annual programme of action for health (2014-2020) supports Member States to undertake the necessary reforms to achieve innovative health systems. It helps them improve access to sustainable health care for citizens. A more general objective is to promote good health and prevent diseases. Finally, it aims at providing well-balanced cross-border health care. The Programme sets its budget at 446 million euro. 